\title{
Patterns of Plasma Oestradiol-17ß in Relation to the Interval from Weaning to Oestrus in Sows
}

Sows generally are anoestrus during lactation. Weaning the litter normally results in a rapid increase in follicular growth that terminates in oestrus and ovulation. Follicular development after weaning is characterized by an elevation in the blood concentrations of oestradiol-17ß $\left(E_{2}\right)$. Although the post-weaning patterns of $\mathrm{E}_{2}$ in blood circulation have been reported previously (Cox \& Britt 1982, Edwards \& Foxcroft 1983, Rojanasthien 1988), the plasma patterns of $E_{2}$ in relation to the interval from weaning to oestrus (WOI), to our knowledge, have not been assessed. The purpose of this study was therefore to relate the blood patterns of $E_{2}$ to the WOI in sows exhibiting their first oestrus within 10 days after weaning.

Twenty primiparous crossbred (Swedish Landrace $\mathrm{x}$ Swedish Yorkshire) sows were brought to the Department of Obstetrics and Gynaecology 4 weeks before expected farrowing. They were kept in individual pens and fed according to the Swedish breeding stock standard (Göransson 1984). The number of piglets was adjusted to uniform size with a minimum of 7 piglets per sow within $24-48 \mathrm{~h}$ after birth. The sows were weighed within 2 days of farrowing and weaning. Jugular vein catheterization was performed during the fourth week of lactation (Rodriguez \& Kunavongkrit 1983). All sows were weaned on day $35 \pm 2$ of lactation. After weaning, oestrous detection was performed in the presence of a boar twice daily at about 0800-0900 and 1500$1600 \mathrm{~h}$. Blood samples were collected in hepa- rinized tubes every $12 \mathrm{~h}$ (at 0900 and $2100 \mathrm{~h}$ ) from 3-5 days before weaning until the appearance of prooestrous symptoms and every $3 \mathrm{~h}$ thereafter until oestrus subsided. Samples were immediately centrifuged after collection and plasma was stored at $-20^{\circ} \mathrm{C}$ until assayed. The sows were slaughtered following their post-weaning oestrus, and the reproductive organs were examined to confirm ovulation.

Plasma concentrations of $E_{2}$ in the samples were determined by radioimmunoassay technique (Boilert et al. 1973, Kunavongkrit et al. 1983). The sensitivity of the assay system was $20.6 \mathrm{pmol} / \mathrm{l}$. The inter-assay variations were 16.9 and $18.6 \%$ for low and high assay controls, respectively. The intra-assay variation calculated from the precision profile was less than $10 \%$ in the ranges between 36.9 and $133.3 \mathrm{pmol} / \mathrm{l}$.

The sows were grouped according to the length of WOI as follow: Gr1: (WOI $=3-4$ days, $\mathrm{n}=7$ ), Gr2: (WOI $=5$ days, $\mathrm{n}=7$ ) and Gr3: (WOI $=6-8$ days, $n=6$ ). The changes in plasma concentrations of $E_{2}$ were studied from the $E_{2}$-patterns of individual sows. The pre-weaning level of $E_{2}$ was defined as the mean of all values obtained before weaning. An elevation of $E_{2}$ after weaning was considered to have occurred when $\mathrm{E}_{2}$ rose above the pre-weaning level plus 2 standard deviations. The results were analysed by leastsquare analysis of variance using the General Linear Model procedure (SAS Institute Inc. 1985). The model for analysing the between- 
group differences in all parameters included the effect of group.

All sows exhibited standing-oestrus with normal ovulation within 8 days after weaning. Changes in plasma levels of $E_{2}$ in relation to WOI are presented in Table 1 . No significant differences in the number of piglets weaned or body weight loss during lactation were observed between the groups. Pre-weaning levels of $E_{2}$ did not differ among the groups of sows. Concentrations of oestradiol measured were, however, just above the detection limit of the assay. If variation in preweaning follicular development existed among the sows, it was too low to be reflected in differences in $\mathrm{E}_{2}$ concentrations.

All sows in our study showed typical patterns regarding the preovulatory rise in plasma $\mathrm{E}_{2}$ prior to oestrus. The shorter interval from weaning to the elevation of $E_{2}$ in Gr1 and $\mathrm{Gr} 2$-sows than in $\mathrm{Gr} 3$-sows $(\mathrm{p}<0.01)$ clearly indicates that follicular development started earlier after weaning in the sows exhibiting the earlier oestrus. The interval from weaning to the start of prooestrus as well as the dura- tion of prooestrus was recently found to be shorter in sows exhibiting oestrus early after weaning than in those coming into oestrus later on (Rojkittikhun et al. 1992). The tendency $(\mathrm{p}<0.1)$ for the interval from the rise in $\mathrm{E}_{2}$ to the onset of oestrus to be shorter in Gr1-sows in the present study thus corresponds well with the duration of prooestrus. The fact that there were no between-group differences in the duration of the $E_{2}$-elevation indicates that follicular maturation after weaning in sows required about the same amount of time regardless of the length of the weaning-to-oestrous interval. Our results indicate that the maximal levels of the preovulatory rise in $E_{2}$ and the number of ovulatory follicles were similar among sows exhibiting oestrus within 8 days after weaning.

Consequently, we suggest that differences in the time interval from weaning to the rise in oestradiol among groups of sows were mainly due to factors other than the stage of follicular development or the size of the follicular population at weaning. The differences in hypothalamic and pituitary responsiveness to weaning

Table 1: Clinical data and patterns of plasma oestradiol-17B $\left(\mathrm{E}_{2}\right)$ in relation to weaning-to-oestrous interval (WOI) in primiparous sows exhibiting oestrus within 8 days after weaning 1 .

\begin{tabular}{llll}
\hline Group & $\mathrm{Gr} 1$ & $\mathrm{Gr} 2$ & $\mathrm{Gr} 3$ \\
\hline WOI (days) & $3-4(\mathrm{n}=7)$ & $5(\mathrm{n}=7)$ & $6-8(\mathrm{n}=6)$ \\
No. of piglets weaned & $9.0 \pm 0.7$ & $9.7 \pm 0.7$ & $10.2 \pm 0.8$ \\
Weight loss during lactation $(\mathrm{kg})$ & $20.4 \pm 4.5$ & $23.3 \pm 4.5$ & $26.8 \pm 4.9$ \\
Pre-weaning levels of $\mathrm{E}_{2}(\mathrm{pmol} / \mathrm{h})$ & $22.9 \pm 2.2$ & $23.4 \pm 2.2$ & $20.2 \pm 2.4$ \\
Maximal levels of $\mathrm{E}_{2}(\mathrm{pmol} / \mathrm{l})$ & $94.6 \pm 6.6$ & $92.0 \pm 6.6$ & $89.8 \pm 7.2$ \\
Interval from weaning to the & & & \\
elevation of $\mathrm{E}_{2}(\mathrm{~h})$ & $22.0 \pm 7.7^{\mathrm{a}}$ & $35.6 \pm 7.7^{\mathrm{a}}$ & $76.2 \pm 8.3^{\mathrm{b}}$ \\
Interval from the rise in $\mathrm{E}_{2}$ to the & & & $85.0 \pm 7.0$ \\
onset of oestrus $(\mathrm{h})$ & $68.3 \pm 6.5$ & $83.0 \pm 6.9$ & $96.7 \pm 8.6$ \\
Duration of the $\mathrm{E}_{2}$-elevation $(\mathrm{h})$ & $76.6 \pm 7.9$ & $89.7 \pm 7.9$ & $18.5 \pm 1.5$ \\
Number of corpora lutea & $19.4 \pm 1.4$ & $17.5 \pm 1.5$ & \\
\hline
\end{tabular}

${ }^{1}$ Data are presented as LSmean \pm SEM. Values within a row without superscript are not significantly different. Values within a row with different superscripts differ significantly $(\mathrm{p}<0.01)$.

${ }^{2}$ Values in $\mathrm{Gr} 1$ tended to be lower than in $\mathrm{Gr} 3(\mathrm{p}<0.1)$. 
and the degree of body weight loss during lactation are probably among the factors involved.

\section{Acknowledgements}

This work was supported by the Swedish Council for Forestry and Agricultural Research. The faculty of Veterinary Medicine, Kasetsart University, Thailand, is acknowledged for granting T. Rojkittikhun study leave.

\section{T. Rojkittikhun, S. Einarsson}

Department of Obstetrics and Gynaecology.

\section{L.-E. Edqvist}

Department of Clinical Chemistry, Faculty of Veterinary Medicine; Swedish University of Agricultural Sciences, Uppsala, Sweden.

\section{References}

Boilert B, Edqvist LE, Johansson EDB, Lindberg P, Martinsson $K$ : The influence of conjugated oestrogens in radioimmunoassay using different antibodies against oestradiol-17B. Steriods 1973, 22, 891-894.

Cox NM, Britt JH: Associations between patterns of serum $\mathrm{LH}$ and changes in oestradiol during the weaning-to-estrus period in sows. J. Anim. Sci. 1982, 55, Suppl.1, 346.

Edwards S, Foxcroft GR: Endocrine changes in sows weaned at two stages of lactation. J. Reprod. Fert. 1983, 67, 161-172.

Göransson L: Förslag till ny utfodringsnorm till suggor. (Feeding recommendation for sows). Sveriges Lantbruksuniversitet, Sweden. Fakta Husdjur 1984, No.3.

Kunavongkrit A, Kindahl H, Madej A: Clinical and endocrinological studies in primiparous zeroweaned sows: 2 . Hormonal patterns of normal cycling sows after zero weaning. Zbl. Vet. Med. A 1983, 30, 616-624.

Rodriguez H, Kunavongkrit A: Chronic venous catheterization for frequent blood sampling in unrestrained pigs. Acta vet. scand. 1983, 24, 318-320.

Rojanasthien S: LH-patterns in jugular plasma and oestradiol-17B and progesterone in utero-ovarian and jugular plasma in primiparous sows around weaning. J. Vet. Med. A 1988, 35, 498505.

Rojkittikhun T, Sterning M, Rydhmer L, Einarsson S: Oestrous symptoms and plasma levels of oestradiol-17B in relation to the interval from weaning to oestrus in primiparous sows. Proc. 12th IPVS Congr. The Hague, The Netherlands 1992, p 485.

SAS Institute Inc.: SAS User's Guide. Cary, NC. 1985, pp. 433-506.

(Received October 9, 1992; accepted November 18, 1992).

Reprints may be requested from: S. Einarsson, Department of Obstetrics and Gynaecology, Faculty of Veterinary Medicine, Swedish University of Agricultural Sciences, S-750 07 Uppsala, Sweden. 
